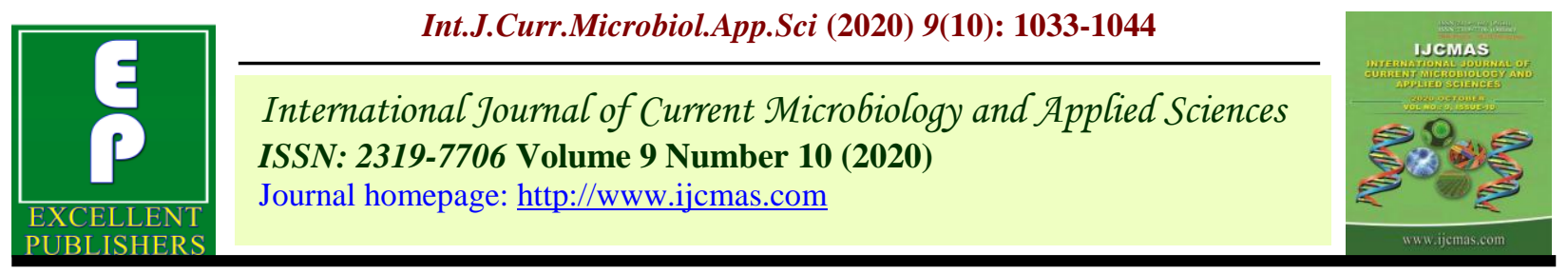

Original Research Article

https://doi.org/10.20546/ijcmas.2020.910.124

\title{
Larval Rearing and Post larval Production of Ganga River Shell Fishes Macrobrachium gangeticum and Macrobrachium malcolmsonii
}

\author{
Suday Prasad ${ }^{*}$
}

Bihar Agricultural University, BPS Agricultural College, Purnea-854302, India

*Corresponding author

\section{A B S T R A C T}

\begin{tabular}{|c|}
\hline Keywords \\
\hline $\begin{array}{l}\text { Shell fish, } \\
\text { Macrobrachium } \\
\text { species, Post larval } \\
\text { production, Ganga } \\
\text { riverPrawn }\end{array}$ \\
\hline Article Info \\
\hline $\begin{array}{l}\text { Accepted: } \\
10 \text { September } 2020 \\
\text { Available Online: } \\
10 \text { October } 2020\end{array}$ \\
\hline
\end{tabular}

The present paper deals with the comparative larval biology and post larval production of Macrobrachium malcolmsonii (Edwards) and Macrobrachium gangeticum (Bate) were studied under captive using 10-19 ppt brackish water to provide information needed for commercial hatchery technology. The incubation period $M$. gangeticum 12-13 days, whereas 12-15 days was found in M. malcolmsonii. Ten thousand larvae of both species were stocked in $300 \mathrm{~L}$ tanks and fed with live Artemia nauplii, egg custard and mussel meet. The water quality parameters were found within suitable ranged. Larvae showing characteristics of 11 distinct larval stages and size range of zoea larvae stage $\mathrm{I}^{\text {st }}$ to XI, 1.85 $\mathrm{mm}$ to $10.58 \mathrm{~mm} \mathrm{M}$. malcolmsoni, whereas the size of $M$. gangeticum larvae ranged 1.80 $\mathrm{mm}$ to $7.29 \mathrm{~mm}$. The first post larvae of both species recorded within 22 days \& 47 days and trials were concluded on the $49^{\text {th }}$ day $\& 63$ day respectively. Production of PL in six trails (three for each) during the first year for M. gangeticum 2854, 3099, and 3249, with 14.27, 15.49 and 16.24 $\mathrm{PL} \mathrm{L}^{-1}$ whereas in case of M. malcolmsonii 2513, 2236 and 2124 with 12.56, 11.18, and $10.62 \mathrm{PL} \mathrm{L}^{-1}$ in trials 1 , 2, and 3, respectively. Post larval production in trials 1,2 , and 3 during the second year of M.gangeticum was recorded at 2916, 3140 and 3185 with $14.58,15.80 \& 15.92 \mathrm{PL} \mathrm{L}^{-1}$ whereas in M. malcolmsonii at 2020, 2443 and 2433 with $10.1,12.21$ and $12.16 \mathrm{PL} \mathrm{L}^{-1}$ respectively. The results on larval biology of both the species indicate the commercial culture and wide scope for the establishments of hatcheries in inland regions.

\section{Introduction}

In developing countries like India, the shell fishes like prawns, crabs and molluscan are very important food stuff due to high protein content and its others medicinal \& nutritional value Prabhakar and Ray (2009). Almost all the major river system of India from north to south and backwaters of Kerala have been recorded with considerable amount of varieties of freshwater prawns Jayachantran and Indira (2010). In India, the largest species of freshwater prawns that are of interest for aquaculture are Macrobrachium rosenbergii, $M$. malocomsonii and $M$. gangeticum respectively, the latter two species are indigenous and can be farmed in monoculture, Mukhopadhyay and Sarangi, (1985); Kanaujia and Mohanty, (2007). The large sized freshwater prawns has great demand for both 
in national and international markets andgreat scope for prawn production in innumerous freshwater bodies throughout North India Prasad and Singh (2006). The species of $M$. gangeticum and $M$. malocomsonii are only available from May to October in the middle stretches of the Ganga around Patna reported by Prasad and Kanaujia, (2006), and size ranged from $65-215 \mathrm{~mm}$ and $60-225 \mathrm{~mm}$ total length whereas weight $5.60-68.00 \mathrm{gms}$ and 6.00-72.00 gms respectively reported by Prasad et al., (2012). The development of hatchery technology of large size Macrobrachium species provides abundance scope for its grow out culture for commercial farming (Tiwari and Holthuis, 1996; Kanaujia et al., 2005; Prasad, 2005; Prasad, 2019). The life history of Gangetic and other large sized freshwater prawn species quite interesting because while the adults inhabit freshwater bodies the berried females migrate to low salinity estuarine water for spawning \& completion of their larval phase of life and the post larvae migrate back to freshwater areas for growth and maturity reported by (Khair et al., 2000; Prasad, 2007; Bauer and Delahoussaye, 2008; Habashy, 2010; Bauer, 2011).

The riverine seed of these Gangatic prawn species has been the only source for its culture in freshwater ponds. In recent time proper culture as a trade has been looked upon with great interest in our country. However, the decline in the juvenile prawn catches and increased demand of freshwater prawns in national as well as international markets need to develop hatchery technology for controlled seed production for sustained prawn yield from freshwater ponds.

In this background an effort has been done to study the comparative larval biology and post larval production of the above said large Macrobrachium species and also distinguish their larval development profiles such as, characteristics, stages, duration of larval cycle and biology in this paper for seed production at commercial levels.

\section{Materials and Methods}

\section{Prawn Collection and Study site}

Berried prawnsof $65-90 \mathrm{~mm}$ total length of $M$. gangeticum and M. malcolmsonii were collected by the help of fisherman using fishing net from the river Ganga near Patna (Bihar) for the period of two years 2000-2001 during breeding season. Prawns were carefully transported to the prawn hatchery at Central Institute of Freshwater Aquaculture, (CIFA), Bhubaneswar, Orissa (Lat. 20॰11"46"-2011"45" N. Long. 85 50"52" $85^{\circ} 51^{\prime \prime}$ E) by using oxygenated plastic begs packing. After prawns were given a dip bath in 0.5-ppm potassium permanganate solution $\left(\mathrm{KM}_{\mathrm{n}} \mathrm{O}_{4}\right)$ for few minutes. They were reared separately in $180 \mathrm{~L}$ transparent glass aquarium filled with 5-8 ppt saline water until hatching. The process of hatching was studied through hand lens and the developing embryo removed from the brood sac observed through compound microscope. An airlift-biofilter device was installed inside the and also provides proper aeration in aquarium. Prawns were fed with egg custard twice-daily $a d$ libitum and leftover food metabolites were siphoned out daily. Seawater collected from Puri seashore to prawn hatchery CIFA and kept under exposure to natural sunlight in FRP tank (Fig. 1).

\section{Experimental set up and animal used}

One rounded plastic pool supported by aluminium lining of $70 \mathrm{~cm}$ height and $90 \mathrm{~cm}$ dia. with $400 \mathrm{~L}$. water holding capacity was used for larval rearing trials. Another plastic drum with $70 \mathrm{~cm}$ height and $80 \mathrm{~L}$ water holding capacity was used for bio-filter, equipped with an airlift. Two units of three 
trials for both species were conducted. Airlift bio-filtration system was adopted following the technique developed and introduced by Kanaujia and Mohanty (1992). After hatching, ten thousand larvae were stocked per tank and salinity of the medium was increased up to $19 \mathrm{ppt}$ gradually by adding hypo-saline water for larval rearing of both species. Water temperature, salinity, dissolved oxygen, total hardness, $\mathrm{pH}$, ammonical nitrogen as were monitored at regular intervals following methods of (APHA, 1985) is given in Table 1 and 2 .

Larvae were fed Artemia nauplii initially, the larvae were fed twice daily morning between 6-7 am and evening 17-18 pm for 15 days. Thereafter feed was supplemented with mussel meat and egg custard given on interval of every six hours by including live feed Artemia nauplii during night at $23-24$ pm. Left over food and other debris was siphoned out daily, aeration provided continuously.

\section{Study animals and measurements}

Microscopic as well as visual observations were made every day to assess the quality of the larvae, their health, survival, growth, developmental stage and swimming behaviors. The general activity of larvae was also observed visually in the tanks. The larval present in $300 \mathrm{~L}$ tank were assessed through 10 randomized samples taken in $100 \mathrm{ml}$ beaker from different parts of the tank. The larvae were counted one by one by pouring them from the beaker of water and mean number of larvae computed to find out the larvae present in the tank during rearing cycle. The distinguishing characteristics features, number of larval stages and size from zoea stage 1 to PL were observed and studied following the guidelines given by (Rao, 1991); Kanaujia and Mohanty (1999) (Fig. 2).

\section{Post larval production and harvesting}

The post larvae were observed, then handmade "Strings of shell" were hung in the larval rearing tanks designed by Kanaujia and Mohanty (1992). Post larvae harvested from the tank every day after lifting out the string shells slowly from the tank were kept in tub having 5-6 liters water medium of the same tank.

The harvested post larvae were acclimatized in freshwater with gradual removal of saline medium by show addition of freshwater in one hour duration (Fig. 3).

\section{Results and Discussion}

The berried female carried the eggs till the hatching. The embryonic development in the eggs accompanied by a gradually changes in the eggs color form green yellow to grey. During incubation period, water temperature ranged from 28.3-30 ${ }^{\circ} \mathrm{C}, \mathrm{pH} \quad 7.5-8.5$ and salinity was maintained 5-8 ppt for both species. The incubation period in $M$. gangeticum was recorded 12-13 days whereas in M. malcolmsonii $12-15$ days. Initial stocking of the larvae in all the twelve trials of both the species during two years werekept uniform (10,000 per tank) but started reducing gradually with the progress of the cycle. The different water quality parameters of the larval rearing trial recorded during 2 years are shown in Table 1 and 2. Temperature: The variation in ambient water temperature during the larval rearing period in $M$. gageticum the SD mean $29.5 \pm 0.36{ }^{\circ} \mathrm{C}$ and $29.9 \pm 0.22^{\circ} \mathrm{C}$ recorded during the first year \& second year in six experimental trials whereas in $M$. malcolmsonii SD mean, water temperature were found $29.8 \pm 0.41^{\circ} \mathrm{C}$ and $29.9 \pm 0.27^{\circ} \mathrm{C}$ during first and second years respectively. Salinity is the most important factor that influences hatching rhythms of freshwater prawn. 
In $M$. gageticum the salinity of larval rearing medium were observed SD mean $16.6 \pm 2.83$ ppt. and $13.5 \pm 1.69$ ppt. during the first year $\&$ second year in six experimental trials whereas in M. malcolmsonii SD mean salinity were found $17.2 \pm 2.32$ ppt. and $16.5 \pm 2.56$ ppt. during the first and second years respectively. The $\mathrm{pH}$ in larval rearing medium of different trials was maintained through the installation of airlift biofilter re-circulatory system, exchange of water and weekly application of calcium sulphate. However, the $\mathrm{SD}$ mean $\mathrm{pH}$ was found $7.7 \pm 0.10$ and $7.6 \pm$ 0.09 during first and second year in M. gangeticum whereas in M. malcolmsonii were observed $7.6 \pm 0.11$ and $7.7 \pm 0.11$ during first and second respectively. Dissolved oxygen (DO): In M. gangeticum the oxygen contents of six larval trials during the first and second year were almost similar, and mean ranged $4.3 \pm 0.18 \mathrm{mg} \mathrm{L}^{-1}$ and $4.3 \pm$ $0.16 \mathrm{mg} \mathrm{L}^{-1}$ during first and second, whereas M. malcolmsonii were found $4.5 \pm 0.19 \mathrm{mg} \mathrm{L}^{-1}$ and $4.3 \pm 0.13 \mathrm{mg} \mathrm{L}^{-1}$ during first and second respectively. Total hardness $(\mathrm{TH})$ : The $\mathrm{TH}$ recorded during the first and second year in M. gangeticum larval rearing trials $2257.5 \pm$ $16.77 \mathrm{mg} \mathrm{L}^{-1}$ and $2279 \pm 12.0 \mathrm{mg} \mathrm{L}^{-1}$ whereas in case of malcolmsonii were found $2279 \pm$ $12.0 \mathrm{mg} \mathrm{L}^{-1}$ and $2277.0 \pm 12.21 \mathrm{mg} \mathrm{L}^{-1}$ in two years.

Total alkalinity (TA): The variation of $\mathrm{TH}$ recorded in first and second year in $M$. gangeticum larval rearing trials $86.7 \pm 4.35 \mathrm{mg}$ $\mathrm{L}^{-1}$ and $86.78 \pm 4.37 \mathrm{mg} \mathrm{L}^{-1}$ whereas in case of malcolmsonii were found $91.9 \pm 3.797 \mathrm{mg} \mathrm{L}^{-1}$ and $87.9 \pm 4.02 \mathrm{mg} \mathrm{L}^{-1}$ during first \& second year respectively.

Ammoniacal nitrogen $\left(\mathrm{NH}_{4}\right)$ : The ammoniacal nitrogen is an important factor, recorded in the six trails during first and second year in $M$. gangeticum was recorded $0.083 \pm 0.007 \mathrm{mg} \mathrm{L}^{-1}$ and $0.115 \pm 0.011 \mathrm{mg} \mathrm{L}^{-1}$ whereas in case of malcolmsonii were found
$0.088 \pm 0.01 \mathrm{mg} \mathrm{L}^{-1}$ and $0.100 \pm 0.009 \mathrm{mg} \mathrm{L}^{-1}$ during first and second year respectively. The characteristics of different developmental larval stages, progressive increase in size during a cycle and duration of each larval stage of both the species in 12 trails presented in (Table 3).

The zoea is planktonic in nature and is photosensitive. The larvae were transparent, translucent and display spot of red and blue chromatophore during the early developmental stages. The newly hatched $M$. malcolmsonii zoea stage 1 larvae recorded with $1.85 \mathrm{~mm}$ size, whereas $M$. gangeticun was $1.80 \mathrm{~mm}$. further, the attainment of the stages in $M$. malcolmsonii up to $5^{\text {th }}$ larval stages was found within 20.5 days and $M$. gangeticum 7.0 days. $M$. malcolmsonii attained comparatively less size $(2.88 \mathrm{~mm})$ than that of $M$. gangeticum $(3.72 \mathrm{~mm})$. Further the stage VI found to pass through 5 more molts in both the species. Where zoea stage XI larvae attained post larval stage within 47 days in $M$. malcolmsonii and this duration was found much shorter in $M$. gangeticum (22 days) (Table 4).

The size at post larvae stage in $M$. malcolmsonii found more $(12.79 \mathrm{~mm})$ than the $M$. gangeticum $(8.81 \mathrm{~mm})$. The larval growth and stages from zoea stage $\mathrm{I}^{\text {st }}$ to zoea stage XI and subsequently attainment of PL stage was not found synchronous during all stages. There are several factors which directly of indirectly affect the growth and development of prawn larvae under culture system. The advance larvae of $M$. gangeticum appear more active compared to similar stage of $M$. malcolmsonii whose larvae display 'serene' moving behavior. The larvae of $M$. gangeticum in all their eleven larval stages are active more upside down with their tail up and the head down obliquely into the water column in the tanks. The 'gun down' movement in advanced stage larvae (stage $\mathrm{X}$ 
and XI) is not extensive as that of $M$. malcolmsonii. The occurrence of first PL was observed on $22^{\text {nd }}$ day and the trails were concluded after 27 days i.e. on $49^{\text {th }}$ day. Daily harvest of PL was done by using string-shell, initiated on the occurrence of first post larvae in the trails. Production of $M$. gangeticum post larvae in three trial during first year recorded 285, 3099 and 3249 with PL per litre (PL/l) was 14.27, 15.49 and 16.24 and the average $3067.3 \& 15.3 \mathrm{PL} / 1$ of three trials, whereas in second year 2916, 3140 and 3185 with mean $3080.3 \pm 144.1$ respectively. PL production per litre ranged from 14.58-15.92 with mean value of $15.40 \pm 0.6 \mathrm{PL} / \mathrm{l}$ respectively (Table 5). In $M$. malcomlsonii first PL was observed on $47^{\text {th }}$ day and trails were concluded after 17 days i.e. on 63 day The PL production of $M$. malcomlsonii found lower than $M$. gangeticum, whereas PL production were recorded during first year 2513, 2236 and 2124 with PL per litre (PL/l) was 12.56, 11.18 and 10.62 an average 2291.5 \& 11.3 PL/1 of three trials, whereas in second year 2020, 2443 and 2433 with mean 2298.6 \pm 241.4 and PL production per liter ranged from 10.1- 12.21 with mean value of $11.7 \pm$ 1.4 PL/1 respectively (Table 5).

In many invertebrates, the degree of tolerance to various physicochemical factors like temperature, salinity and $\mathrm{pH}$ varies during ontogeny Manoj and Appukuttan, (2003). The temperature of water regulates the metabolisms and growth of various larval stages of prawn (Rao, 1991; Prasad and Singh, 2007). The optimum salinity requirement for brooders of large sized Macrobrachium species for better hatching and survival of hatching reported by (Jayalakshmy and Natrajan, 1996; Soundarapandian et al., 2009). In the present study incubation period in $M$. gangeticum was recorded 12-13 days whereas in $M$. malcolmsonii 12-15 days. Incubation period in $M$. rosenbergii ranged from 18-24 days for different size groups of prawn reported by (Habashy, 2010).

Table.1 Average, SD mean water quality parameters of larval rearing trials of M. gangeticum during first and second years

\begin{tabular}{|c|c|c|c|c|c|c|c|}
\hline \multicolumn{8}{|c|}{ First year } \\
\hline Trial & $\begin{array}{l}\text { Water temp. } \\
{ }^{0} \mathrm{C}\end{array}$ & $\begin{array}{c}\text { Salinity } \\
\text { ppt }\end{array}$ & $\mathrm{pH}$ & $\begin{array}{l}\mathrm{DO} \\
\mathrm{mg} / \mathrm{l}\end{array}$ & $\begin{array}{l}\mathrm{TH} \\
\mathrm{mg} / \mathrm{l}\end{array}$ & $\begin{array}{l}\mathrm{TA} \\
\mathrm{mg} / \mathrm{l}\end{array}$ & $\begin{array}{l}\mathrm{NH} 4 \\
\mathrm{mg} / \mathrm{l}\end{array}$ \\
\hline T-1 & 29.4 & 16.3 & 7.7 & 4.3 & 2248.3 & 85.9 & 0.088 \\
\hline T-2 & 29.6 & 16.7 & 7.7 & 4.3 & 2259.4 & 86.3 & 0.078 \\
\hline T-3 & 29.5 & 16.7 & 7.7 & 4.2 & 2264.7 & 85.8 & 0.080 \\
\hline $\begin{array}{c}\text { Mean } \\
\pm \mathrm{SD}\end{array}$ & $\begin{array}{l}29.5 \\
0.36\end{array}$ & $\begin{array}{l}16.6 \\
2.88\end{array}$ & $\begin{array}{c}7.7 \\
0.10\end{array}$ & $\begin{array}{c}4.3 \\
0.18\end{array}$ & $\begin{array}{c}2257.5 \\
16.77\end{array}$ & $\begin{array}{l}86.7 \\
4.35\end{array}$ & $\begin{array}{l}0.083 \\
0.007\end{array}$ \\
\hline \multicolumn{8}{|c|}{ Second year } \\
\hline Trial & $\begin{array}{l}\text { Water temp. } \\
{ }^{0} \mathrm{C}\end{array}$ & $\begin{array}{c}\text { Salinity } \\
\text { ppt }\end{array}$ & $\mathrm{pH}$ & $\begin{array}{c}\mathrm{DO} \\
\mathrm{mg} / \mathrm{l}\end{array}$ & $\begin{array}{c}\mathrm{TH} \\
\mathrm{mg} / \mathrm{l}\end{array}$ & $\begin{array}{l}\mathrm{TA} \\
\mathrm{mg} / \mathrm{l}\end{array}$ & $\begin{array}{l}\mathrm{NH} 4 \\
\mathrm{mg} / \mathrm{l}\end{array}$ \\
\hline T-1 & 29.9 & 13.3 & 7.6 & 4.4 & 2263.6 & 90.1 & 0.125 \\
\hline T-2 & 29.8 & 13.4 & 7.6 & 4.3 & 2284.6 & 87.8 & 0.106 \\
\hline $\mathbf{T}-\mathbf{3}$ & 29.9 & 13.8 & 7.7 & 4.3 & 2282.0 & 82.4 & 0.115 \\
\hline $\begin{array}{l}\text { Mean } \\
\pm \text { SD }\end{array}$ & $\begin{array}{l}29.9 \\
0.22\end{array}$ & $\begin{array}{l}13.5 \\
1.69\end{array}$ & $\begin{array}{c}7.6 \\
0.09\end{array}$ & $\begin{array}{c}4.3 \\
0.16\end{array}$ & $\begin{array}{c}2276.7 \\
12.80\end{array}$ & $\begin{array}{l}86.7 \\
4.37\end{array}$ & $\begin{array}{l}0.115 \\
0.011\end{array}$ \\
\hline
\end{tabular}


Table.2 Average, SD mean water quality parameters of larval rearing trials of $M$. malcolmsonii during first and second years

\begin{tabular}{|c|c|c|c|c|c|c|c|}
\hline \multicolumn{8}{|c|}{ First year } \\
\hline Trial & $\begin{array}{l}\text { Water temp. } \\
{ }^{0} \mathrm{C}\end{array}$ & $\begin{array}{c}\text { Salinity } \\
\text { ppt }\end{array}$ & $\mathrm{pH}$ & $\begin{array}{l}\mathrm{DO} \\
\mathrm{mg} / \mathrm{l}\end{array}$ & $\begin{array}{c}\mathrm{TH} \\
\mathrm{mg} / \mathrm{l}\end{array}$ & $\begin{array}{c}\mathrm{TA} \\
\mathrm{mg} / \mathrm{l}\end{array}$ & $\begin{array}{l}\mathrm{NH} 4 \\
\mathrm{mg} / \mathrm{l}\end{array}$ \\
\hline $\mathbf{T}-\mathbf{1}$ & 29.9 & 17.2 & 7.6 & 4.5 & 2269 & 91.4 & 0.083 \\
\hline $\mathbf{T}-2$ & 29.8 & 17.3 & 7.7 & 4.5 & 22578 & 91.6 & 0.082 \\
\hline $\mathbf{T}-3$ & 29.8 & 17.3 & 7.6 & 4.5 & 22691 & 92.7 & 0.100 \\
\hline $\begin{array}{l}\text { Mean } \\
\pm \text { SD }\end{array}$ & $\begin{array}{l}29.8 \\
0.41\end{array}$ & $\begin{array}{l}17.2 \\
2.32\end{array}$ & $\begin{array}{c}7.6 \\
0.11\end{array}$ & $\begin{array}{c}4.5 \\
0.19\end{array}$ & $\begin{array}{r}22579 \\
12.00\end{array}$ & $\begin{array}{c}91.9 \\
3.797\end{array}$ & $\begin{array}{l}0.088 \\
0.001\end{array}$ \\
\hline \multicolumn{8}{|c|}{ Second year } \\
\hline Trial & $\begin{array}{l}\text { Water temp. } \\
{ }^{0} \mathrm{C}\end{array}$ & $\begin{array}{c}\text { Salinity } \\
\text { ppt }\end{array}$ & $\mathrm{pH}$ & $\begin{array}{l}\mathrm{DO} \\
\mathrm{mg} / \mathrm{l}\end{array}$ & $\begin{array}{c}\mathrm{TH} \\
\mathrm{mg} / \mathrm{l}\end{array}$ & $\begin{array}{c}\mathrm{TA} \\
\mathrm{mg} / \mathrm{l}\end{array}$ & $\begin{array}{l}\mathrm{NH} 4 \\
\mathrm{mg} / \mathrm{l}\end{array}$ \\
\hline $\mathbf{T - 1}$ & 29.9 & 16.5 & 7.7 & 4.3 & 2266.7 & 89.9 & 0.100 \\
\hline $\mathbf{T}-2$ & 29.9 & 16.2 & 7.7 & 4.3 & 2280.0 & 89.6 & 0.101 \\
\hline $\mathbf{T}-\mathbf{3}$ & 29.9 & 16.8 & 7.6 & 4.3 & 2284.3 & 84.1 & 0.098 \\
\hline $\begin{array}{l}\text { Mean } \\
\pm \text { SD }\end{array}$ & $\begin{array}{l}29.9 \\
0.27\end{array}$ & $\begin{array}{l}16.5 \\
2.56\end{array}$ & $\begin{array}{c}7.7 \\
0.11\end{array}$ & $\begin{array}{c}4.3 \\
0.13\end{array}$ & $\begin{array}{c}2277.0 \\
12.21\end{array}$ & $\begin{array}{l}87.9 \\
4.02\end{array}$ & $\begin{array}{l}0.100 \\
0.009\end{array}$ \\
\hline
\end{tabular}

Table.3 Characteristics of different larval stages of two large Macrobrachium species

\begin{tabular}{|c|c|c|}
\hline Stages & M. malcolmsonii & M. gangeticum \\
\hline I & $\begin{array}{l}\text { Body transparent, telson triangular } \\
\text { posterior edge broad, abdomen with six } \\
\text { somites and last is not separated from } \\
\text { telson. Eyes large sessile. }\end{array}$ & $\begin{array}{l}\text { Eye sessile, body transparent, } \\
\text { chromatophore on the basis of the } 2^{\text {nd }} \text { and } \\
3^{\text {rd }} \text { walking legs, Greenish chromatophore } \\
\text { seen on Cephalothorax. }\end{array}$ \\
\hline II & $\begin{array}{l}\text { A pair of supra-orbited and Branchio- } \\
\text { stegal spines present. Pleura of } \\
\text { abdominal somite developed } 1^{\text {st }}, 2^{\text {nd }} \text {, and } \\
3^{\text {rd }} \text {, periopodbiramous } 5^{\text {th }} \text { periopod } \\
\text { uniramous. Eyes large stalk. }\end{array}$ & $\begin{array}{l}\text { Bluish green chromatophore at the mid } \\
\text { dorsal, base of } 2^{\text {nd }}, 3^{\text {rd }}, 4^{\text {th }} \text { walking leg } \\
\text { red. Lower portion of eye stalk very } \\
\text { prominent periphery is little brownish. } \\
\text { Telson with } 8 \text { pair of cilia. }\end{array}$ \\
\hline III & $\begin{array}{l}\text { Uropod developed, one rostrum teeth } \\
\text { appear, } 6^{\text {th }} \text { abdominal somite separated } \\
\text { from telson. Base of walking legs } \\
\text { reddish and body light yellowish. }\end{array}$ & $\begin{array}{l}\text { Body transparent, Red chromatophore at } \\
\text { anus. Reddish chromatophore at the } \\
\text { ischium of } 1^{\text {st }}, 2 \text { nd, 3rdwalking leg. Base } \\
\text { of the eye reddish black. }\end{array}$ \\
\hline IV & $\begin{array}{l}\text { Rostrum with } 2 \text { teeth, uropod biramous. } \\
\text { Body yellowish. At the base of eye stalk } \\
\text { red mid dorsal blue red. }\end{array}$ & $\begin{array}{l}\text { Body white, dot like red region found on } \\
\text { basis, and merus portion of } 2^{\text {nd }}, 3^{\text {rd }} \\
\text { walking leg. }\end{array}$ \\
\hline $\mathrm{V}$ & $\begin{array}{l}\text { Red chromatophore at } 4^{\text {th }} \text { pleopod base. } \\
\text { Two rostral teeth. }\end{array}$ & $\begin{array}{l}\text { Body white, red tinge on the ischium and } \\
\text { merus of } 1^{\text {st }}, 2^{\text {nd }} \text { and } 3^{\text {rd }} \text { pereopods. }\end{array}$ \\
\hline VI & $\begin{array}{l}\text { Body yellowish. Deep red on } 4^{\text {th }} \text { pleopods } \\
\text { extending toward } 3^{\text {rd }} \text {, pleopod buds } \\
\text { appear } 2^{\text {nd }}, 3^{\text {rd }}, 4^{\text {th }} \text { more developed. }\end{array}$ & $\begin{array}{l}\text { Red chromatophore at the posterior lateral } \\
\text { side of the carapace, at the } 4^{\text {th }} \text { pleopod and } \\
\text { at the merus of } 2^{\text {nd }} \text { chelate legs. }\end{array}$ \\
\hline VII & Pleopodbiramus, chromatophore & Red chromatophore at the merus of $2^{\text {nd }}$ \\
\hline
\end{tabular}




\begin{tabular}{|c|c|c|}
\hline & extending towards $3^{\text {rd }}$, and dorsal side. & chelate leg. \\
\hline VIII & $\begin{array}{l}\text { Rostrum with } 2 \text { teeth } 3-4 \text { spine on } 2^{\text {nd }} \\
\text { teeth. Pleopod buds with ciliated except } \\
5^{\text {th }} \text { Body yellowish, Red chromatophore } \\
\text { on } 4^{\text {th }}, 3^{\text {rd }} \text { peleopod. }\end{array}$ & $\begin{array}{l}\text { Chromaotphore at the merus of the } 2^{\text {nd }} \\
\text { walking leg and at base of } 4^{\text {th }} \text { pleopod, } \\
\text { Body white little straw colour. Rostrum } \\
\text { with } 2 \text { teeth } 3 \text {-spine near } 1^{\text {st }} \text { teeth. }\end{array}$ \\
\hline IX & $\begin{array}{l}\text { Appendix interna develop of the } \\
\text { endopod of } 2^{\text {nd }} \text { pleopod. Red } \\
\text { chromatophore increases on body. }\end{array}$ & $\begin{array}{l}\text { Appendix interma develop of the indopod } \\
\text { of } 2^{\text {nd }} \text { pleopod. Straw color develops on } \\
\text { carapace and red at anus. }\end{array}$ \\
\hline $\mathrm{X}$ & $\begin{array}{l}\text { Rostrum with } 2 \text { big and } 4-5 \text { small teeth } \\
\text { and } 4 \text { spines on } 2^{\text {nd }} \text { rostrum teeth. Red } \\
\text { chromatophore at ventral side covering } \\
\text { the } 4^{\text {th }}, 3^{\text {rd }} \text {, and } 2^{\text {nd }} \text { pleopod. }\end{array}$ & $\begin{array}{l}\text { Body transparent. Red chromatophore on } \\
\text { the merus of } 2^{\text {nd }} \text { walking leg, base of } \\
4^{\text {th }} \text { pleopod. Dorsal. Rostrum with } 2 \text { big } \\
\text { and 3-4 small spines on dorsal side. }\end{array}$ \\
\hline XI & $\begin{array}{l}\text { strum with } 2 \text { big and } 10-11 \text { small } \\
\text { th lower portion of } 1^{\text {st }} \text { and } 2^{\text {nd }} \text { teeth } \\
\text { rated } 2^{\text {nd }} \text { teeth with } 5 \text { spine }(4 \text { big one } \\
\text { all). Red chromatophore at the base of } \\
\text { 3rd and } 2^{\text {nd }} \text { pleopod. }\end{array}$ & $\begin{array}{l}2 \text { big and } 8 \text { small teeth on the dorsal side } \\
\text { of rostrum. Lower portion of the } 1^{\text {st }} \text { and } \\
2^{\text {nd }} \text { teeth secreted, } 2^{\text {nd }} \text { teeth with } 3-4 \\
\text { spines. Red chromatophore at merus of } \\
2^{\text {nd }} \text { chalate leg and base of } 4^{\text {th }} \text { pleopod }\end{array}$ \\
\hline $\begin{array}{c}\text { Post } \\
\text { Larvae }\end{array}$ & $\begin{array}{l}\text { Size } 12.79 \mathrm{~mm} \text { All teeth on dorsal side } \\
\text { of rostrum equal size, on the dorsal side } \\
\text { of the rostrum } 10-11 \text { teeth gap, } 1^{\text {st }} \text { teeth } \\
\text { with } 4-5 \text { spine, } 2^{\text {nd }} \text { teeth with } 3 \text { spine } \\
\text { then } 2 \text { spine on each teeth. }\end{array}$ & $\begin{array}{l}\text { Size } 8.81 \mathrm{~mm} \text {, Red chromophore ventral } \\
\text { side }\left(5^{\text {th }} \text { to } 1^{\text {st }} \text { pleopods }\right) \text {. Dorsal rostrum } \\
\text { teeth equal } \& 10-11 \text { teeth } \& \text { in continuous } \\
\text { row. } 4 \text { spine on } 1^{\text {st }} \& 3 \text { spine on } 2^{\text {nd }} \text { teeth } \\
\text { and } 2 \text { spine on each teeth. }\end{array}$ \\
\hline
\end{tabular}

Table.4 Size and duration of various larval stages of two large Gangetic shell fish Macrobrachium species during larvae culture

\begin{tabular}{|c|c|c|c|c|}
\hline \multirow{2}{*}{ Stages } & \multicolumn{2}{|c|}{ M. malcolmsonii } & \multicolumn{2}{c|}{ M. gangeticum } \\
\cline { 2 - 5 } & Size $(\mathrm{mm})$ & Duration (days) & Size $(\mathrm{mm})$ & Duration (days) \\
\hline I & 1.85 & 1.85 & 1.80 & 1.5 \\
\hline II & 2.03 & 2.03 & 2.22 & 2.5 \\
\hline III & 2.2 & 2.2 & 2.81 & 3.5 \\
\hline IV & 2.45 & 2.45 & 3.33 & 4.5 \\
\hline V & 2.88 & 2.88 & 3.72 & 7.0 \\
\hline VI & 4.16 & 4.16 & 4.34 & 10.5 \\
\hline VII & 5.06 & 5.06 & 5.04 & 13.5 \\
\hline VIII & 6.14 & 6.14 & 5.52 & 15.5 \\
\hline IX & 7.56 & 7.56 & 6.06 & 17.0 \\
\hline X & 9.37 & 9.37 & 6.51 & 18.5 \\
\hline XI & 10.58 & 10.58 & 7.21 & 20.0 \\
\hline PL & 12.79 & 12.79 & 8.81 & 22.0 \\
\hline
\end{tabular}


Table.5 Post larval production of two large Gangetic Macrobrachium species

\begin{tabular}{|c|c|c|c|c|c|c|c|c|}
\hline \multicolumn{4}{|c|}{ Macrobrachium gangeticum } & \multicolumn{3}{c|}{ Macrobrachium malcolmsonii } \\
\hline & \multicolumn{2}{|c|}{ First year } & \multicolumn{2}{c|}{ Second year } & \multicolumn{2}{c|}{ First year } & \multicolumn{2}{c|}{ Second year } \\
\hline Trial & Total PL & PL/L & Total PL & PL/L & Total PL & PL/L & Total PL & PL/L \\
\hline T-1 & 2854 & 14.27 & 2916 & 14.58 & 2513 & 12.56 & 2020 & 10.1 \\
\hline T-2 & 3099 & 15.49 & 3140 & 15.80 & 2236 & 11.18 & 2443 & 12.21 \\
\hline T-3 & 3249 & 16.24 & 3185 & 15.92 & 2124 & 10.62 & 2433 & 12.16 \\
\hline Mean & 3067.3 & 15.3 & 3080.3 & 15.40 & 2291.5 & 11.3 & 2298.6 & 11.7 \\
SD & 199.4 & 1.0 & 144.1 & 0.6 & 200.2 & 1.0 & 241.4 & 1.4 \\
\hline
\end{tabular}

Fig.1 Collections and packaging of adult \& berried prawn from Ganga neat Patna

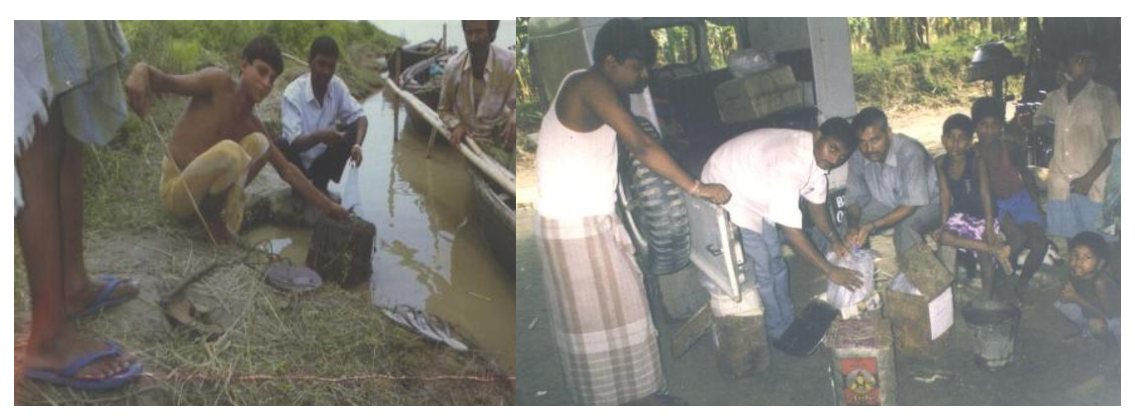

Fig.2 Berried prawn and larval feeding in experimental tanks at CIFA, Prawn Hatchery

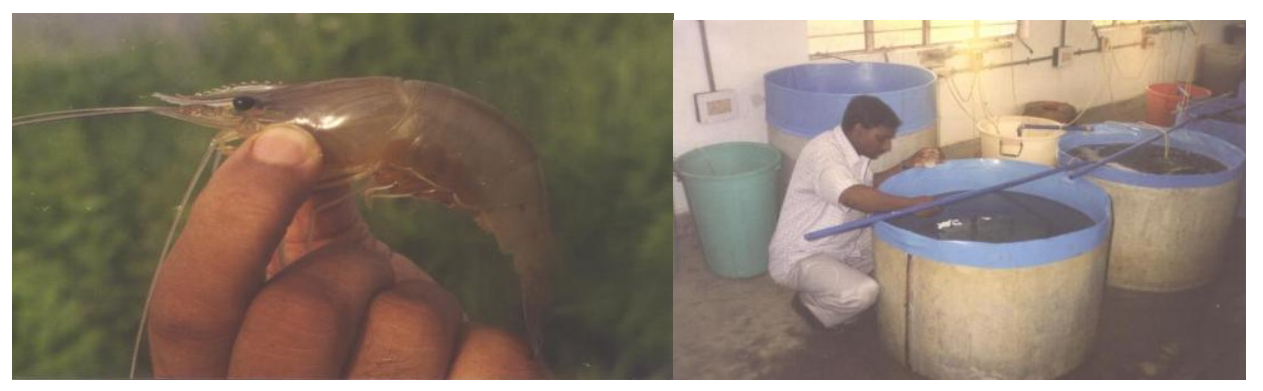

Fig.3 Microscopic observation of larvae and harvesting of post larvae at CIFA

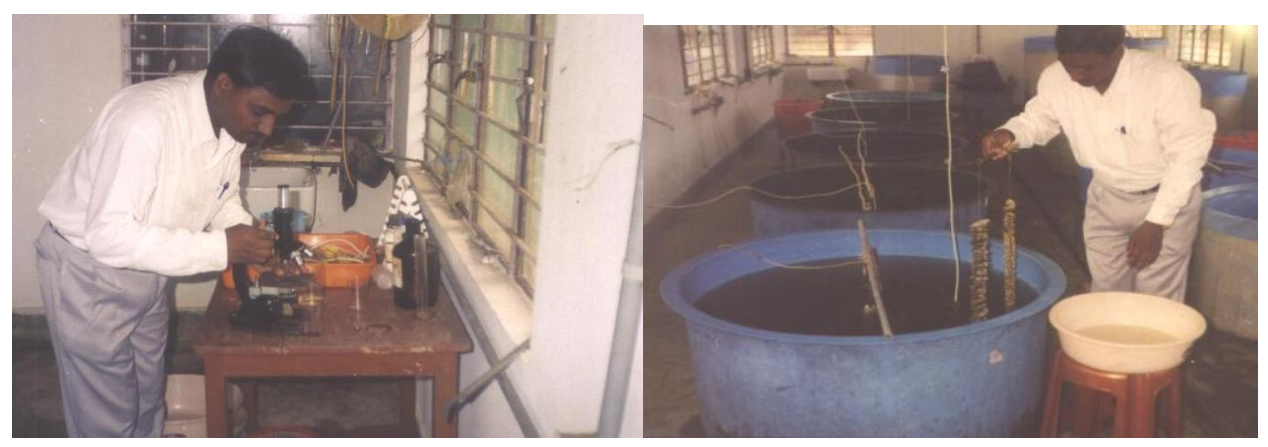


The colour of the eggs gradually become yellow to grey and when the larvae inside the eggs found fully developed then became deep grey. Suddenly the eggshell was broken and the telson thrashed out followed by the head, with a vigorous flex, stretch of the body the hatched zoea larvae started swimming actively in water column, these some observations were reported by (Kanaujia and Mohanty, 1999; Kanaujia et al., 2005; Prasad, 2007; Habashy, 2010; Prasad, 2012). During the larval rearing period the salinity varied from 12-16 ppt in M. gangeticum, whereas in M. malcolmsonii varied from 12-19 ppt. Salinity influence the incubation and hatching rhythum of freshwater prawn, Jayalakshmy and Natrajan, (1996). Kanaujia and Mohanty, (1992); Prasad, (2019) have reported that the salinity range between $18-20$ ppt was optimal for the better growth and post larval production of $M$. malcolmsonii and 12-16 ppt for $M$. gangeticum. Lower salinity range may prolong the duration of metamorphosis with a poor survival rate (Rao, 1991; Kanaujia and Mohanty, 1992). In the present study, the increase in $\mathrm{pH}$ during the larval rearing period was observed and maintained within the range of 7.5 to 7.7 by periodic application of calculated amount of calcium sulphate. New and Singholka (1985); Prasad and Singh, (2007) have also reported a suitable range of $\mathrm{pH}$ ranged 7.5-8.5 during larval rearing of $M$. rosenbergii. In the present study, the oxygen ranged between 4.0-4.7 $\mathrm{L}^{-1}$ with a very narrow range of variation. The wide variations of DO were reported by (Kanaujia et al., 2005; Prasad and Singh, 2008, Prasad, 2019). Total hardness affects the growth of the larvae and mineralization of carapace. Kanaujia and Mohanty (1992); Kanaujia and Mohanty, 2007) reported higher hardness level 2000$5200 \mathrm{mg} / \mathrm{l}$ in $M$. malcolmsonii and $M$. gangeticum during larval rearing period.

Feeding of newly hatched larvae plays a crucial role in the success of larvae culture, since heavy mortality of early larval stages and asynchronous metamorphosis occurs when larvae are exposed to starvation after hatching (Simoes, et al., 2002; Calado, et al., 2005). Newly hatched Artemia nauplii constitute the principal live food used in larvae culture of crustaceans of commercial value (Barros and Valenti, 2003; Araujo and Valenti, 2007). Some authors believed that Artemia nauplii suffice to produce $M$. rosenbergii Post larvae (Devresse et al., 1990; Lavens et al., 2000). However, several others believed that Artemia nauplii do not fulfill the nutritional requirements of larvae during the last Zoeal stages and therefore, recommend the use of supplemental diets (Daniels et al., 1992).New and Singholka 1985, recommend egg custard from stage III on wards (about the fourth day of culture), while Daniles, et al., (1992) recommend diet supplementation from stage $\mathrm{V}$ to VI (between the $8^{\text {th }}$ and $10^{\text {th }}$ days). In present study initially, larvae were fed with Artemia nauplii twice daily during 6 am and 6 Pm for one week followed by supplementary feed i.e. egg custard and mussel meat four times a day included during rest period of both species of larvae. The newly hatched zoea stage I was found transparent or translucent, red and blue chromatophore during early stage inof both species. The later stage larvae were very active and display darting movements along the side of the tank, some behaviour was found more or less similar to those of $M$. rosenbergii, Rao, 1991; Prasad and Singh 2006). The distinguishing characteristics of each eleven stages of both species are more or less similar to those recorded in $M$. rosenbergii. The presence of red chromatophore on the entire merus region and the $2^{\text {nd }}$ chelate legs during stage $\mathrm{V}$ to $\mathrm{XI}$ is important distinguishing characteristics of $M$. gangeticum which is not found in $M$. rosenbergii and M. malcolmsonii (Rao, 1991; Prasad and Singh, 2006). The growth of larvae, rate of increase in the larval sizes of $M$. gangeticum and M. malcolmsonii initiated 
with more or less similar size (1.8 and 1.85 $\mathrm{mm}$ ) at stage I and size varied from 8.8112.79 while attaining to post larval stage between 22 and 47 days respectively. In between these stages the variations in progressive increase in size and duration for subsequent stages were recorded greatly in both species. The larval development in $M$. gangeticum and M. malcolmsonii in all the trails progressed at the same. The growth and development of $M$. malcolmsonii have been studied (Kanaujia and Mohanty 1992). Prasad and Singh (2008), reported, larvae of $M$. rosenbergii normally takes 1 to 3 days to reach I stage to next stage. The duration of larval cycle of $M$. malcolmsonii was kept for 63 days whereas in $M$. gangeticum it was 49 days. But the occurrence of first post larvae in $M$. malcolmsonii was recorded on $47^{\text {th }}$ and in $M$. gangeticum on $22^{\text {nd }}$ day (Table 3 ). The occurrence of first post larvae of most the reports varied from each other's Kanaujia and Mohanty (1992) obtained first few post larvae in $M$. malcolmsonii within 40 to 53 days in natural brackish water and on $41^{\text {st }}$ day in artificial seawater, whereas, Rao (1991) observed them on $52^{\text {nd }}$ days. The present study revealed that most of the larvae in $M$. gangeticum metamorphosed into post larvae within 49 days of larval cycle. The total production of PL in six trial during first and second years were maximum 3249 in Trial-3 followed by $3185,3140,3099,3140,2916$, and 2855 in trials 6,5,2,4 \& 1 @ 14.27, 15,49, 16.24, first year and 14.58, 15.80, 15.92, PL/1 in trial 1, 2, 3, 4, 5, 6 respectively. Whereas in M. malcolmsonii in six trial during two years recorded maximum 2513 in trial-1 followed by $2443,2433,2236,2124$ and 2020 in trials $5,6,2,3$, \& 4 and PL/1 were recorded 12.56, $11.18,10.62,10.1,12.21,12.16$ in trials 1,2,3,4,5, and 6 respectively. Rao (1991); Kanaujia and Mohanty (1992) also reported duration of 60 days or more for the metamorphosis of complete batch of larvae of M. malcolmsonii. The comparative results on larval biology of both the species has opened a field for its adoption to the inland regions as well as North-East states of the country where the both the species available in river Ganga and Brahmaputra. They are also larger species, tastier, hardy and possess good market demand like other larger Macrobrachium species.

\section{Acknowledgement}

Author wishes to express his gratitude to the Director, CIFA, Bhubaneswar for the permission to carry out the research work and Guide, Dr. D. R. Kanaujia and Dr. A. K. Patra for providing the excellent laboratory facilities.

\section{References}

APHA, (1985). Standard Methods for the Examination of Water and Wastewater $16^{\text {th }}$ edn. American Public Health Association, Washington D. C. 1260 pp.

Araujo, M. C., and Valenti, W. C. (2007). Feeding habit of the Amazon river prawn Macrobrachium amazonicum larvae, Aquaculture, 265, 187 - 193.

Bauer, R. T., and Dalahoussaye, J. (2008). Life history migration of the Amphidromous river shrimp Macrobrachium ohine from a continental large river system, Journal of Crustacean Biology, 28 (4): 622632.

Bauer, R. T., (2011). Amphidromous and Migration of freshwater shrimp, II delivery of hatching larvae to the sea, return juveniles upstream migration and human impacts: New Frontiers in Crustacean Biology: 157-168.

Barros, H. P. and Valenti, W. C., (2003). Food intake of Macrobrachium rosenbergii (De man) during larval development, Aquaculture, 216, 165- 
176.

Calado, R., Figuciredo, J., Rosa, R., Nunes, M.L. and Narcico, L., (2005). Larval culture of Monaco shrimp Lysmata seticaudata (Caridea, Hippolytidae) effect of temperature rearing density and larval diet, Aquaculture, 245, 221237.

Devresse, B., Romdhane, M. C., Buzzi, M., Rasowo, J. Leger, P., Brown, J., and Sorgloos, P., (1990). Improved larvae culture outputs in the giant freshwater prawn Macrobrachium rosenbergii fed a diet of Artemia enriched with n-3 HUFA and phospholipid, World. Aqua. 21, 123-125.

Daniels, W. H., Abramo, L. R., and Parseval,, D., (1992). Design and management of a closed recirculating "clear water" hatchery system for freshwater prawns, Macrobrachium rosenbergii. J. Shellfish Research, 11, 65-71.

Habashy, M. M. (2010). On the breeding behavior and reproduction of the freshwater prawn, Macrobrachium rosenbergii (De man) under laboratory condition. African J. Biol. Sci. 6(2):63-73.

Jayachandran, K. V. and Indira, B. (2010). Sustainable exploitation of freshwater prawn diversity of India for foods and livelihood security with emphasis on planning. Indian J. Sci. Res. 1(2): 127 $-132$.

Jayalakshmy, B., and Natrajan, P. (1996). Influence of salinity on fertilization and hatching of Macrobrachium idella, under laboratory condition. J. Aqua. Trop. 11, 35-38.

Kanaujia, D.R., and A.N. Mohanty. (1992). Breeding and large scale seed production of the Indian river prawn Macrobrachium malcolmsonii (Edwards). Aquaculture, 2: 7- 16.

Kanaujia, D. R. Mohanty, A. N., Mitra, G., and Prasad, S. (2005). Breeding and seed production of the Ganga river prawn Macrobrachium gangeticum (Bate) under captive condition. Asian Fisheries Science 18 (3); 371-381.

Kanaujia, D. R. and Mohanty, A. N., (1999). Role of temperature variation on larval growth and post larval production of Macrobrachium malcolmsonii (Edwards). J. Aqua. Trop. 14 (3): 187192.

Kanaujia, D. R., and Mohanty, A. N., (2007). Seed production of gangetic prawn, Indian Farming, 56 (10): 10-12.

Khair, S. A., Hossain, M. A. and Parveen, S., (2000). Distribution of Macrobrachium rosenbergii in three rivers of Paikgaicha, Bangladesh. Bangladesh J. Fish. Res. 4 (2): 199202.

Lavens, P., Hongrod, S., and Sorgeloos, P, (2000). Larvae prawn feeds and the dietary importance of Artemia In: New, MB. Valentti, WC. (Eds) Freshwater prawn culture. Blackwell, Oxford 91-111.

Manoj, N. R., and Appukuttan, K. K., (2003). Effect of temperature on the development, Growth, Survival and settlement of green mussel Pernaviridis (Linnaeus, 1758) Aquaculture Research, 34, 1037-1045.

Mukhopadhyay, S. K., and Sarangii, N., (1985) Survival, Growth and Production of freshwater prawn Macrobrachium malcolmsonii. Environ. Ecol. 3(2):198-201.

New, M. B., and Singholka S. (1985). Freshwater prawn farming. A manual for the culture of Macrobrachium rosenbergii, FAO, Fisheries Technical Paper, 222pp. 118.

Prabhakar, A., and Roy, S. P. (2009) Ethnomedicinal uses of some shell fishes by people of Koshi river basin on north Bihar, India. Ethno Med. 3(1):1-4

Prasad, S., (2005). Studies on the freshwater 
prawn fishery of river Ganga with special reference to the larval biology of larger Macrobrachium Species. Ph.D thesis, Utkal University, Bhubaneswar, Orissa.

Prasad, S., and Singh, H. (2006). Macrobrachium rosenbergii (de Man) completes larval cycle in close recirculatory hatchery at Ludhiana, Fishing Chimes. 26(1): 145 - 147.

Prasad, S., and Kanaujia, D. R. (2006) Availability and breeding behavior of ganga river prawn Macrobrachium gangeticum (Bate) and Macrobrachium malcolmsonii (Edwards). Asian Fishery Science. 19(4): 377-388.

Prasad, S., and Singh, H. (2007). Breeding and larval biology of giant freshwater prawn Macrobrachium rosenbergii (De man) in Punjab. Proc. Zool. Soc. India. 6(2): 1 - 8.

Prasad, S., and Singh, H. 2008. Monoculture Growth, Breeding and Fecundity of Giant Freshwater Prawn Macrobrachium rosenbergii (De man) in Haryana. Ind. J. Env. \& Ecop. 15(3): 683-687.

Prasad, S. Kanaujia, D. R., and Patra, A. 2012. Diversity abundance and composition of large freshwater prawn species in the Ganga river system. The Bioscan 7 (4): 685- 689.

Prasad, S. (2019). Outdoor Hatchery Larval Biology and Seed Production of Ganga River Prawn Macrobrachium gangeticm (Bate). Curr. J. Appl. Sci. and Techn. 33(3): 1 - 7.

Rao, K. J., (1991). Breeding and larval rearing of the freshwater prawn Macrobrachium malcolmsonii (Edwards), Journal of Aquaculture in the Tropics, 6: 99- 106.

Simoes, F., Ribeiro, F., and Jones, D. A. (2002) Feeding early larval stages of fire shrimp Lysmatadebelius (Caridea, Hippolytidae). Aquaculture Inter. 10, $349-360$.

Soundarapandian, P., Prakash, K. S., and Dinakaran, G. K. (2009). Simple Technology for the hatchery seed production of Giant Paleamonid prawn Macrobrachium rosenbergii (De man). International Journal of Animal and Veterinary Adavance 1 (2):49-53.

Tiwari, K. K., and Holthuis, L. B., (1996). The identity of Macrobrachium gangeticum (Bate), 1868 (Decapoda, Caridea, Palemonidae). Crustaceana. 69(7): 922-925.

\section{How to cite this article:}

Suday Prasad. 2020. Larval Rearing and Post larval Production of Ganga River Shell Fishes Macrobrachium gangeticum and Macrobrachium malcolmsonii. Int.J.Curr.Microbiol.App.Sci. 9(10): 1033-1044. doi: https://doi.org/10.20546/ijcmas.2020.910.124 